\title{
Purpureocillium lilacinum and Trichoderma virens for biological control of trichostrongylid parasites of sheep: an in vitro evaluation
}

\author{
Purpureocillium lilacinum e Trichoderma virens no controle biológico de \\ tricostrongilídeos de ovinos: uma avaliação in vitro \\ Cristiane Telles Baptista1; Andrios da Silva Moreira1; Fernando de Souza Maia Filho'; \\ Júlia de Souza Silveira Valente ${ }^{1}$; Natália Berne Pinto ${ }^{2}$; Waldenis Pereira da Trindade Junior ${ }^{1}$; \\ Caroline Quintana Braga1; Luciana Pötter3; Daniela Isabel Brayer Pereira ${ }^{1,4 *}$ (1)

\begin{abstract}
${ }^{1}$ Laboratório de Micologia, Programa de Pós-graduação em Microbiologia e Parasitologia, Instituto de Biologia, Universidade Federal de Pelotas - UFPel, Pelotas, RS, Brasil

${ }^{2}$ Laboratório de Helmintologia, Programa de Pós-graduação em Microbiologia e Parasitologia, Instituto de Biologia, Universidade Federal de Pelotas - UFPel, Pelotas, RS, Brasil

${ }^{3}$ Centro de Ciências Rurais, Universidade Federal de Santa Maria - UFSM, Santa Maria, RS, Brasil

${ }^{4}$ Departamento de Microbiologia e Parasitologia, Instituto de Biologia, Universidade Federal de Pelotas - UFPel, Pelotas, RS, Brasi
\end{abstract}

How to cite: Baptista CT, Moreira AS, Maia Filho FS, Valente JSS, Pinto NB, Trindade Junior WP, et al. Purpureocillium lilacinum and Trichoderma virens for biological control of trichostrongylid parasites of sheep: an in vitro evaluation. Braz J Vet Parasitol 2020; 29(4): e006120. https://doi.org/10.1590/S1984-29612020085

\begin{abstract}
The study evaluated the ovicidal activity of enzymatic extracts of Purpureocillium lilacinum and Trichoderma virens against trichostrongylid eggs from sheep. Filtered extract (FE) and macerated crude extract (MCE) were prepared from fungal cultures in minimal broth. In the experiment, 100 trichostrongylid eggs, obtained from the feces of naturally infected sheep, were exposed to fungal extracts for 24 and 48 hours $/ 25^{\circ} \mathrm{C}$. In the control group, eggs were incubated in minimal broth. The number of L1 larvae was ascertained. Each treatment consisted of four repetitions and the experiment was repeated five times. It was observed that the effect of FE and MCE of $P$. lilacinum and $T$. virens on egg hatchability differed from that of the control group. MCE of $T$. virens and $P$. lilacinum showed higher ovicidal activity than FE over both periods and at 48 hours of exposure, respectively. From the percentage reductions in hatchability of the eggs, MCE was shown to be superior to FE for both fungi. This study demonstrated the ovicidal potential of these fungi against trichostrongylid eggs. However, further studies are needed in order to identify the molecules responsible for the ovicidal effects, and to evaluate the behavior of fungal extracts in biotic and abiotic interactions.
\end{abstract}

Keywords: Biological control, nematophagous fungi, enzymatic extracts, gastrointestinal nematodes, trichostrongylid eggs.

\begin{abstract}
Resumo
O estudo avaliou a atividade ovicida de extratos enzimáticos de Purpureocillium lilacinum e Trichoderma virens sobre ovos de tricostrongilídeos de ovinos. Extrato filtrado (EF) e extrato macerado bruto (EMB) foram preparados a partir de culturas fúngicas em caldo mínimo. No ensaio experimental, 100 ovos de tricostrongilídeos, obtidos de fezes de ovinos naturalmente infectados, foram expostos durante 24 e 48 horas $/ 25^{\circ} \mathrm{C}$ aos extratos dos fungos. No grupo controle, os ovos foram incubados em caldo mínimo. O número de larvas L1 foi determinado. Cada tratamento consistiu em quatro repetições e o experimento foi repetido cinco vezes. Observou-se que o efeito ovicida do EF e EMB de P. lilacinum e $T$. virens diferiu do grupo controle. O EMB de $T$. virens e $P$. lilacinum evidenciou atividade ovicida superior ao EF em ambos os períodos avaliados e em 48 horas de exposição, respectivamente. O percentual de redução de eclodibilidade evidenciou que o EMB foi superior ao EF em ambos os fungos. Este estudo demonstra o potencial ovicida desses fungos sobre ovos de tricostrongilídeos.
\end{abstract}

Received March 18, 2020. Accepted August 19, 2020

*Corresponding author: Daniela Isabel Brayer Pereira. E-mail: danielabrayer@gmail.com

This is an Open Access article distributed under the terms of the Creative Commons Attribution License, which permits unrestricted use distribution, and reproduction in any medium, provided the original work is properly cited. 
No entanto, estudos adicionais são necessários para identificar as moléculas responsáveis pelo efeito ovicida, bem como avaliar o comportamento dos extratos fúngicos em interações bióticas e abióticas.

Palavras-chave: Controle biológico, fungos nematófagos, extratos enzimáticos, nematódeos gastrointestinais, ovos de tricostrongilídeos.

Gastrointestinal nematodes of the family Trichostrongylidae, including the genera Haemonchus, Trichostrongylus, Ostertagia, and Cooperia, are the parasites that most frequently infect ruminants. Haemonchus contortus is the main endoparasite of sheep, followed by Trichostrongylus spp.. They cause serious economic losses because they delay growth, decrease production and eventually lead to the death of infected hosts (Amarante et al., 2014). According to Kaplan (2020), for many years, the parasites were controlled in small ruminants by the use of anthelmintics, and this approach has been quite effective. Nevertheless, nowadays we are suffering high levels of anthelmintic resistance in different drug classes, involving almost all of the most economically important parasites of all livestock species. Additionally, the presence of chemical residues in meat and milk and ecotoxicity have stimulated research seeking alternative control measure (Sutherland \& Leathwick, 2011; Amarante et al., 2014; Burke \& Miller, 2020). In this context, use of nematophagous fungi as biocontrol agents is an interesting, viable, promising and ecologically friendly tool (Burke \& Miller, 2020). Even though the mechanisms of pathogenicity that are used by nematophagous fungi have not yet been fully elucidated, the evidence suggests that both mechanical and enzymatic action is involved in penetration and digestion of the nematode cuticle (Yang et al., 2007).

Previous studies using the fungus Trichoderma spp. were conducted by Maia et al. $(2013,2017)$ on Toxocara canis eggs, and these studies demonstrated its efficiency in controlling this parasite. Similarly, Purpureocillium lilacinum (Paecilomyces lilacinus) has been shown to have potential biocontrol effect on parasites of medical and veterinary relevance, including T. canis (Carvalho et al., 2009; Maia et al., 2019), Taenia saginata (Braga et al., 2008a), and Moniezia sp. (Braga et al., 2008b).

The life cycle characteristics of trichostrongylids, which include short-term egg hatching (Amarante et al., 2014), hamper the mechanism of colonization by ovicidal fungi. However, Braga et al. $(2010,2011)$ and Hofstätter et al. (2017) showed that in vitro enzymatic extracts of Pochonia chlamydosporia, P. lilacinum and Trichoderma virens had the capacity to inhibit hatching of the eggs of Cyathostominae and Ancylostoma spp., which are geohelminths whose eggs also hatch in the environment in a short time.

This study aimed to evaluate the ovicidal activity of extracts of Purpureocillium lilacinum and Trichoderma virens against trichostrongylid eggs in sheep.

Two fungal isolates were used in this study: Purpureocillium lilacinum (Paecilomyces lilacinus) (CG 193), provided by the National Center for Research on Genetic Resources and Biotechnology, Embrapa (Cenargen); and Trichoderma virens (MICLAB 008) from the Mycology Laboratory, Department of Microbiology and Parasitology, Universidade Federal de Pelotas, previously identified by DNA sequencing. The cultures were kept in tubes containing potato dextrose agar (PDA) at $4{ }^{\circ} \mathrm{C}$, and were then subcultured with PDA in Petri dishes and incubated at $25^{\circ} \mathrm{C}$ for 10 days. Following the methodology described by Hofstätter et al. (2017), from cultures in minimal broth, two different extracts of the fungi were prepared, as follow. Filtered extract (FE) was obtained by passing the supernatant broth through Whatman paper filter no. 1. Macerated crude extract (MCE) was prepared by firstly separating the mycelium from the supernatant medium and then subjecting it to maceration in three baths of liquid nitrogen until a powder was obtained, which was immediately resuspended in the supernatant medium. These extracts were prepared and used on the same day.

Approximately $50 \mathrm{~g}$ of feces were collected directly from the rectal ampulla of 32 sheep that were naturally infected with gastrointestinal nematodes. The feces were then packed in isothermal boxes, sent to the laboratory and immediately processed for individual quantification of nematode eggs in sheep faeces (Gordon \& Whitlock, 1939). Samples showing around 1000 eggs/gram of feces were subjected to the egg retrieval technique previously described by Hubert \& Kerboeuf (1992). In short, the feces were diluted and macerated in warm water and filtered through $1 \mathrm{~mm}, 105 \mu \mathrm{m}, 55 \mu \mathrm{m}$ and $25 \mu \mathrm{m}$ cross-linked sieves. The eggs retained in the smallest diameter mesh were washed in sterile distilled water and centrifuged at $3000 \mathrm{rpm}$ for 5 minutes. The supernatant was discarded and the precipitate was suspended in hypersaturated saline $(\mathrm{NaCl}, 35 \%)$ and centrifuged again under the same conditions. Following this, the supernatant was filtered through $25 \mu \mathrm{m}$ sieves and the eggs collected were washed in distilled water. Ten microliters of this solution were analyzed between slides and cover slips, and the eggs were counted.

$500 \mu \mathrm{L}$ aliquots of each fungal extract (FE and MCE) of $T$. virens and $P$. lilacinum were poured into tissue culture dishes, and $500 \mu \mathrm{L}$ of a suspension containing approximately 100 trichostrongylid eggs was added. For control 
group dishes, $500 \mu \mathrm{L}$ of suspension containing approximately 100 trichostrongylid eggs was added to $500 \mu \mathrm{L}$ of minimal broth. The dishes were incubated at $25^{\circ} \mathrm{C}$ for 24 or 48 hours. Each treatment consisted of four repetitions and the experiment was repeated five times at different times.

After 24 hours of incubation, a reading was made using a stereoscopic magnifying glass and the total number of trichostrongylid larvae (hatched eggs) present in each dish of the treated and control groups was ascertained. The same reading methodology was used on the dishes that were incubated for 48 hours.

The experimental design was completely randomized, with three treatments, four replicates and five repetitions. Because the response variable did not present normal distribution, the data were subjected to the Kruskal-Wallis nonparametric test. When differences between treatments were found, the averages were compared using the Bonferroni test (Coimbra et al., 2004). The analyses were carried out using the SAS statistical software (SAS Institute, 2012), taking into account a 5\% probability. For each experiment, the percentage of eggs hatched was also calculated by using the following equation, as described by Braga et al. (2010, 2011): Reduction $\%=\left(\right.$ average $n^{\circ}$ of larvae in control group - average $n^{\circ}$ of larvae in treated group) $\times 100$, divided by (average $\mathrm{n}^{\circ}$ of larvae in control group).

Table 1 shows the results from the interactions of the FE and MCE fungal extracts of $P$. lilacinum and $T$. virens with trichostrongylid eggs. The statistical analysis revealed differences $(P<0.05)$ in the numbers of larvae between the formulations of each fungus and the control group, over both periods evaluated. With the exception of FE of $P$. lilacinum, it was observed that the action of the extracts from the two fungal species over 24 and 48 hours did not differ $(P>0.05)$.

For T. virens, MCE was superior to FE over both 24 and 48 hours of egg exposure to the fungus $(\mathrm{P}<0.05)$. On the other hand, the action of MCE of $P$. lilacinum did not differ from FE, over the $24 \mathrm{~h}$ period. However, both MCE ( 24 and $48 \mathrm{~h}$ ) and FE $(24 \mathrm{~h})$ activity were superior to FE over the $48 \mathrm{~h}$ evaluation period $(\mathrm{P}<0.05)$. Additionally, it was observed that the percentage reduction of hatchability caused by the MCE extract of both fungal isolates was higher than that of FE over the periods evaluated (Table 1).

Nematophagous fungi have been investigated as an important tool for biological control of pathogenic parasites because of their ability to capture and infect nematodes (Burke \& Miller, 2020).

Table 1. Average larval count and percentage reduction in hatching of the eggs of trichostrongylids exposed to different fungal extracts of Purpureocillium lilacinum and Trichoderma virens, over 24 and 48 hours.

\begin{tabular}{|c|c|c|c|c|}
\hline Fungus (extract) & Larvae 24 hours & Larvae 48 hours & $\begin{array}{l}\% \text { egg reduction } \\
\text { hatched } 24 \text { hs }\end{array}$ & $\begin{array}{l}\% \text { egg reduction } \\
\text { hatched } 48 \text { hs }\end{array}$ \\
\hline \multicolumn{5}{|l|}{ T. virens } \\
\hline MCE & $1.20^{c}$ & $5.60^{c}$ & 98.70 & 94.06 \\
\hline $\mathrm{FE}$ & $8.70^{\mathrm{b}}$ & $15.45^{b}$ & 90.61 & 83.61 \\
\hline Control & $92.75^{a}$ & $94.30^{\mathrm{a}}$ & & \\
\hline \multicolumn{5}{|l|}{ P. lilacinum } \\
\hline MCE & $6.25^{c}$ & $9.30^{c}$ & 93.26 & 90.13 \\
\hline FE & $7.45^{c}$ & $24.50^{b}$ & 91.96 & 74.01 \\
\hline Control & $92.75^{a}$ & $94.30^{\mathrm{a}}$ & & \\
\hline
\end{tabular}

Averages followed by different letters in the column and line differed statistically $(P<0.05)$. MCE: macerated crude extract; FE: filtered extract.

The life cycle characteristics of trichostrongylids, which include short-term egg hatching and the presence of infective L3 larvae in pastures (Amarante et al., 2014), have led to development of studies on larva-predatory nematophagous fungi (Santurio et al., 2011). However, research evaluating the ovicidal activity of fungi on the eggs of this group of parasites is scarce.

The present study demonstrated that MCE and FE fungal extracts prepared from $T$. virens and $P$. lilacinum cultures showed significant ovicidal activity against the eggs of trichostrongylids that parasitize sheep.

In a previous study, Hofstätter et al. (2017) demonstrated the ovicidal action of different extract preparations from four fungal isolates, including T. virens and P. lilacinum, on eggs of Ancylostoma spp. Although these authors 
observed that the extracts evaluated had significant ovicidal effect, they showed that MCE and FE from P. lilacinum did not differ between each other in their ovicidal action. The results obtained in the present study were similar, since no significant differences in ovicidal activity against trichostrongylid eggs were observed between FE and MCE from P. lilacinum when their action was evaluated over 24 hours. However, it was found that the ovicidal activity of FE from this fungus was lower over 48 hours, which suggests that the enzymatic activity of the extract was lost because of the time that elapsed.

In addition, the results from the present study showed that the action of MCE and FE from $T$. virens differed from each other, and from the control group, over the periods evaluated. However, no differences in extract activity were observed between the 24 and 48 hour periods. Similar results were reported by Hofstätter et al. (2017), from evaluating the activity of FE and MCE from T. virens against eggs of Ancylostoma spp. On the other hand, the hatchability percentages reported by Hofstätter et al. (2017) for both P. lilacinum and $T$. virens were lower than those observed in the present study.

It was seen in this study that the percentage reductions in hatchability caused by MCE from both fungi were higher than $\mathrm{FE}$, reaching values of over $90 \%$. Hofstätter et al. (2017) suggested that the higher MCE activity could be due to the presence of intracellular enzymes that are released during the maceration process. This, added to the action of extracellular enzymes secreted in the supernatant, would increase the efficacy of the fungal extract.

Although the pathogenicity mechanisms used by nematophagous fungi have not yet been fully elucidated, the evidence shows that extracellular hydrolytic enzymes are involved in nematode cuticle penetration and digestion (Yang et al., 2007).

Though the genus Trichoderma is predominantly used in biological control of phytonematodes, studies have shown that it also has action against $T$. canis eggs (Maia et al., 2013, 2017). This demonstrates the potential of this fungus for use as a biocontrol agent. The use of enzymatic extracts from $T$. virens in the present study demonstrated the ovicidal potential of this fungal genus against trichostrongylid eggs, with percentage reductions in hatchability of over $83 \%$.

Studies on other genera of nematophagous fungi have been developed for the purpose of evaluating the enzymatic activity of filtered cultures or purified enzymes against the larvae and/or eggs of gastrointestinal helminths in animals. Similar to the results obtained in the present study, Braga et al. $(2010,2011)$ used crude enzymatic extracts of the fungus Pochonia chlamydosporia on cyathostomin and Ancylostoma spp. and were able to reduce egg hatchability by $72.8 \%$ and $76.8 \%$, respectively.

It is believed that the inhibitory action of these extracts against trichostrongylid egg hatchability occurs through the activity of enzymes that are secreted by the fungi. According to Romero (1984), eggs of worms in the phylum Nematoda have an internal lipoprotein layer, a chitinous intermediate layer and an external yolk layer, which may be susceptible to the action of these enzymes. Additionally, there is evidence that proteases, collagenases and chitinases are involved in penetration and digestion of the nematode cuticle, as seen in $\mathrm{H}$. contortus (Yang et al., 2007). However, the enzymes present in the enzymatic extracts evaluated in the present study have not been characterized and further studies to determine the enzymatic profile of these fungal isolates remain necessary.

The hatchability of the eggs of trichostrongylids that parasitize sheep was significantly reduced through exposure to extracts of $P$. lilacinum and $T$. virens fungi over 24 and 48 -hour periods, thus showing the potential of these fungi as biocontrol agents. However, further studies are needed on order to identify and characterize the molecules responsible for the effects that were observed, and to evaluate the behavior of fungal extracts, in experiments involving biotic and abiotic interactions.

\section{Acknowledgements}

This work was supported by the Brazilian National Council for Scientific and Technological Development (Conselho Nacional de Desenvolvimento Científico e Tecnológico, CNPq) and the Coordination Office for the Improvement of Higher-Education Personnel (Coordenação de Aperfeiçoamento de Pessoal de Nível Superior, CAPES), under Finance code 001.

\section{References}

Amarante AFT, Ragozo A, Silva BF. Os parasitas de ovinos. São Paulo: Editora Unesp Digital; 2014. http://dx.doi. org/10.7476/9788568334423. 
Braga FR, Araújo JM, Silva AR, Araújo JV, Carvalho RO, Soares FEF, et al. Ação ovicida do extrato bruto enzimático do fungo Pochonia chlamydosporia sobre ovos de Ancylostoma sp. Rev Soc Bras Med Trop 2011; 44(1): 116-118. http://dx.doi.org/10.1590/ S0037-86822011000100027. PMid:21340423.

Braga FR, Araújo JV, Araújo JM, Carvalho RO, Silva AR, Campos AK, et al. Ovicidal activity of Paecilomyces lilacinus on Moniezia sp. eggs. J Helminthol 2008b; 82(3): 241-243. http://dx.doi.org/10.1017/S0022149X08977488. PMid:18613986.

Braga FR, Araújo JV, Araújo JM, Carvalho RO, Silva AR. Efeito do fungo Paecilomyces lilacinus sobre ovos de Taenia saginata. Rev Soc Bras Med Trop 2008a; 41(6): 686-688. http://dx.doi.org/10.1590/S0037-86822008000600026. PMid:19142455.

Braga FR, Araújo JV, Carvalho RO, Silva AR, Araújo JH, Soares FEF, et al. Ovicidal action of a crude enzymatic extract of the fungus Pochonia chlamydosporia against cyathostomin eggs. Vet Parasitol 2010; 172(3-4): 264-268. http://dx.doi.org/10.1016/j. vetpar.2010.05.011. PMid:20627419.

Burke JM, Miller JE. Sustainable approaches to parasite control in ruminant livestock. Vet Clin North Am Food Anim Pract 2020; 36(1): 89-107. http://dx.doi.org/10.1016/j.cvfa.2019.11.007. PMid:32029191.

Carvalho RO, Araújo JV, Braga FR, Araújo JM, Silva AR, Tavela AO. Predatory activity of nematophagous fungi on infective larvae of Ancylostoma spp.: evaluation in vitro and after passing through the gastrointestinal tract of dogs. J Helminthol 2009; 83(3): 231-236. http://dx.doi.org/10.1017/S0022149X08158965. PMid:19144215.

Coimbra JLM, Carvalho FIF, Oliveira AC. Fundamentos do SAS aplicado à experimentação agrícola. Pelotas: UFPel; 2004.

Gordon HM, Whitlock HV. A new technique for counting nematode eggs in sheep faeces. J Counc Sci Ind Res 1939; 12(1): 50-53.

Hofstätter BD, Fonseca AOS, Maia FS Fo, Silveira JS, Persici BM, Pötter L, et al. Effect of Paecilomyces lilacinus, Trichoderma harzianum and Trichoderma virens fungal extracts on the hatchability of Ancylostoma eggs. Rev Iberoam Micol 2017; 34(1): 28-31. http://dx.doi.org/10.1016/j.riam.2016.04.004. PMid:27810261.

Hubert J, Kerboeuf D. A microlarval development assay for the detection of anthelmintic resistance in sheep nematodes. Vet Rec 1992; 130(20): 442-446. http://dx.doi.org/10.1136/vr.130.20.442. PMid:1621342.

Kaplan RM. Biology, epidemiology, diagnosis, and management of anthelmintic resistance in gastrointestinal nematodes of livestock. Vet Clin North Am Food Anim Pract 2020; 36(1): 17-30. http://dx.doi.org/10.1016/j.cvfa.2019.12.001. PMid:32029182.

Maia FS Fo, Fonseca AOS, Valente JSS, Baptista CT, Moreira AS, Botton SA, et al. Exposure of Toxocara canis eggs to Purpureocillium lilacinum as a biocontrol strategy: an experimental model evaluation. Rev Bras Parasito/ Vet 2019; 28(1): 91-96. http://dx.doi. org/10.1590/s1984-29612019007. PMid:30892465.

Maia FS Fo, Vieira JN, Berne MEA, Stoll FE, Nascente PS, Pötter L, et al. Fungal ovicidal activity on Toxocara canis eggs. Rev Iberoam Micol 2013; 30(4): 226-230. http://dx.doi.org/10.1016/j.riam.2012.12.009. PMid:23402830.

Maia FS Fo, Fonseca AOS, Persici BM, Silveira JS, Braga CQ, Pötter L, et al. Trichoderma virens as a biocontrol of Toxocara canis: in vivo evaluation. Rev Iberoam Micol 2017; 34(1): 32-35. http://dx.doi.org/10.1016/j.riam.2016.06.004. PMid:28109772.

Romero HQ. Parasitología y enfermedades parasitárias de animales domésticos. México, Limusa; 1984.

Santurio JM, Zanette RA, Silva AS, Fanfa VR, Farret MH, Ragagnin L, et al. A suitable model for the utilization of Duddingtonia flagrans fungus in small-flock-size sheep farms. Exp Parasitol 2011; 127(4): 727-731. http://dx.doi.org/10.1016/j.exppara.2011.01.013. PMid:21272579.

SAS Institute. 2012. SAS 9.4 for windows. Cary: SAS Institue Inc.

Sutherland IA, Leathwick DM. Anthelmintic resistance in nematode parasites of cattle: a global issue? Trends Parasito/ 2011; 27(4): 176-181. http://dx.doi.org/10.1016/j.pt.2010.11.008. PMid:21168366.

Yang J, Tian B, Liang L, Zhang K. Extracellular enzymes and the pathogenesis of nematophagous fungi. Appl Microbiol Biotechnol 2007; 75(1): 21-31. http://dx.doi.org/10.1007/s00253-007-0881-4. PMid:17318531. 